\title{
A Facile Synthesis with One Step of Disperse Azo Dyes to be Applied as Nano-Inks in Textile Printing
}

\author{
Kawther Ahmed ${ }^{1,2^{*} \mathbb{D}}$, Asmaa Shahin ${ }^{1(\mathbb{D})}$, Amira Ragheb ${ }^{1 \mathbb{D}}$, Heba El-Hennawi ${ }^{1(\mathbb{D})}$ \\ 1 National Research Centre (Scopus affiliation ID 60014618), Textile Industries Research Division, Dyeing, Printing and \\ Textile Intermediate Department, 33 El-Behouth St. (former El-Tahrir str.), Dokki, P.O. 12622, Giza, Egypt; \\ kawther_zaher@yahoo.com (K.A.); asmaa_shahine@yahoo.com (A.S.); amira_zaher@yahoo.com (A.R.); \\ skybird740@yahoo.com (H.e.-H.); \\ 2 Department of Physics, College of Science in Uglet Asugour, Qassim University, Buraydah, Kingdom of Saudi Arabia A; \\ kawther_zaher@yahoo.com (K.A.); \\ * Correspondence: kawther_zaher@yahoo.com;
}

Scopus Author ID 22933707500

Received: 13.10.2020; Revised: 10.12.2020; Accepted: 12.12.2020; Published: 16.12.2020

Abstract: Simple one-step synthesis has been optimized to prepare heterocyclic azo dyes using silicasupported boron tri-fluoride $\left(\mathrm{BF}_{3} \cdot \mathrm{SiO}_{2}\right)$ as a catalyst to promote diazotization and combination of heterocyclic amines with different heterocyclic couplers at room temperature. The structure of the synthesized compounds was proved using different techniques. Nano inks were prepared by microencapsulation technique using these synthesized dyes under ultra-sonication for $10 \mathrm{~min}$. The inks were used in digital printing techniques for cotton and polyamide fabrics. The fastness properties of the prints were measured. The printed fabrics have an excellent washing fastness and good light fastness values.

Keywords: synthesis; chemistry; dyes; ink; chemistry; printing and chemistry.

(C) 2020 by the authors. This article is an open-access article distributed under the terms and conditions of the Creative Commons Attribution (CC BY) license (https://creativecommons.org/licenses/by/4.0/).

\section{Introduction}

Azo dyes are organic compounds consisting of two organic groups bonded together via coupling reactions to give colored compounds [1]. Azo dyes may contain one or more azo groups. They constitute more than half of the dyes used today. They differ in the degree of their complexity, according to the number of the azo groups and the number and nature of the oxochrome groups found there $[2,3]$.

Most of the commercial dyes belong to azo dyes due to the flexibility in their preparation, use, and possession of various properties [4]. Azo dyes are very important compounds because of their various applications; they are widely used in many different fields such as medical, pharmaceutical, food, cosmetic textile, and leather industries [5-7]. Moreover, these dyes are used are in other applications such as heat transfer printing [8], Ink Jet Printing, lasers [9], and fuel cells [10], sensitized solar cell dyes [11], and indicators [12].

A diazotization process usually prepares azo dyes, and the aromatic or heterocyclic amine is initially converted to a diazonium salt [13]. The reaction occurs at a low temperature $\left(0-5^{\circ} \mathrm{C}\right)$ in the presence of sodium nitrite $\left(\mathrm{NaNO}_{2}\right)$ and an acid such as $\mathrm{HCl}$ and $\mathrm{H}_{2} \mathrm{SO}_{4}$. The resulting diazonium complex can interact with different compounds such as phenol, naphthol, or amine, forming the azo dye at the end [14]. 
The conventual methodology for preparing azo dyes has many drawbacks, such as the use of significant quantities of acids, toxic, costly solvents, and environmentally hazardous preparation methods [15]. Therefore, new studies have tended to introduce grinding techniques as eco-friendly and safe methods $[12,16]$. The grinding technique gives cunning simplicity, major selectivity, plain work, lower reaction times, and better yields. Nowadays, heterogeneous solid acids and their nanostructure have been used to prepare azo dyes using the grinding method. Previous studies represented that boron trifluoride diethyl etherate $\left(\mathrm{BF}_{3} . \mathrm{OEt}_{2}\right)$ is used as a catalyst in the synthesis of many organic materials through the reaction of its fumes with the moisture of the air to form hydrofluoric acid. Therefore, using this catalyst in a liquid state is onerous, and the solid-state is required.

Furthermore, Aromatic diazonium salts, in comparison, are hazardous, lacking solubility and/or costly. Filimonov et al. have shown that in the presence of trifluoromethanesulfonic acid, several stable and healthy arene arenas of $\mathrm{ArN}_{2}+\mathrm{TfO}$ can easily and at high yields be obtained diazotization of Tertbutyl nitrite anilines. Arene diazonium triflates in dry conditions are relatively stable in the dry state. [17].

In the textile industry, silicone production is revolutionizing. It plays an important part in the manufacturing process, such as water repellent [18], flame retardant [19], antibacterial [20,21], pH-temperature thermosensitive [21,22], and improving dyeing properties [23-26].

Silica supported boron tri-fluoride $\left(\mathrm{BF}_{3} . \mathrm{SiO}_{2}\right)$ is a reusable and most effective catalyst for promoting the synthesis of azo dyes from aromatic amines at a very short time, with excellent stability and high yield. However, no reaction takes place when using $\mathrm{BF}_{3}$ etherate [27-29].

This study represents a solvent-free, rapid one-pot method, an efficacious path for preparing heterocyclic azo dyes. The process of diazotization and coupling is carried out at room temperature in the presence of nano $\mathrm{BF}_{3} . \mathrm{SiO}_{2}$ as an acidic catalyst. The dye's structures are confirmed using spectral analysis. The synthesized dyes are used as inkjet printing of cotton and polyamide fabrics.

\section{Materials and Methods}

\subsection{Materials and reagents.}

Fabrics: nonwoven Egyptian cotton and polyamide fabrics were supplied by Misr ElMahalla Co., Egypt.

Chemicals: Heterocyclic coupler (benzothiazole-2-amine and 5-phenyl-thiazole-2amine, 5-methyl-thiazole-2-amine), silica-supported boron trifluoride $\left(\mathrm{BF}_{3} . \mathrm{SiO}_{2}\right), 2,2^{\prime}-$ oxydiethanol, propane-1,2,3-triol, urea, polyvinyl alcohol (PVA) sodium hydroxide and deionized distilled water. All chemicals are laboratory grade and supplied by Sigma-Aldrich Company.

\subsection{Synthesis of dyes.}

According to Filimonov and co-workers, [30] the free grinding diazotization process was applied to synthesis the new dyes. The mixture of a heterocyclic amine $(0.01 \mathrm{~mol})$, silicasupported boron tri-fluoride $\left(\mathrm{BF}_{3} . \mathrm{SiO}_{2} ; 0.15 \mathrm{~mol}\right)$, and sodium nitrite $(0.01 \mathrm{~mol})$ was ground for three min, at room temperature. Then $1 \mathrm{ml}$ deionized water was added and under stirring for 2 mins. A heterocyclic coupler $(0.01 \mathrm{~mol})$ was added to the mixture under stirring for 2 mins to obtain the dyes (see Scheme 1). The prepared dyes are dissolved in $20 \mathrm{ml}$ chloroform 
and filtrated to isolate the catalyst. The products were recrystallized from $20-50 \mathrm{ml}$ ethanol. The completion of diazotization was verified via IR spectra. The final product was characterized using elemental analysis, ${ }^{1} \mathrm{H}-\mathrm{NMR},{ }^{13} \mathrm{C}-\mathrm{NMR}$, and Mass spectra.

\subsection{Preparation of inks.}

The microencapsulation technique is used to convert the prepared dyes to inks. A dyeto-polymer ratio of 2:1 was prepared for six inks. The ink was prepared by this formulation: Dye dispersion $8 \%, 2,2$-Oxydiethanol $10 \%$, Propane-1,2,3-triol $10 \%$, Urea $5 \%$, Polyvinyl alcohol (PVA) $4 \%$ and deionized distilled water $63 \%$.

The polymer which contains the $\mathrm{COOH}$ group surrounds the dye particle (shell-core). The attraction force between the dye molecule and the polymer dominates the dispersion; the particle stability is achieved by repulsion force between the particles in water and the polymerpolymer entropic effect [31].

The ink components were mixed by ultrasonic (Sonics and materials INC model VCX 750 volts $230 \mathrm{vac}$ ) at $100 \mathrm{rpm}$ for 30 minutes until a homogeneous solution was obtained. Then, sodium hydroxide ( $10 \%$ by weight) was added to control the ink $\mathrm{pH}$ to a range of $7-9$. The inks were later filtered through a filtering sieve with $8 \mu \mathrm{m}$ pore size. After the inks had been prepared, they were stored in capped glass vessels and placed in a desiccator to avoid absorption of moisture from the air [31-34]. Then the inks were loaded into the inking unit of the inkjet printer (hong Jet-8420).

\subsection{Measurements.}

Melting points were taken on Electro-thermal IA 9000 series digital melting point apparatus. A Varian Mercury VX-300 NMR spectrometer was used for NMR measurements. Dimethyl sulphoxide was run on NMR spectra at $300 \mathrm{MHz}$ (DMSO-d6).

Transmission Electron Microscopy (TEM) JEOL JEM - 2100 (200 KV) instrument was used for obtaining the TEM images. Samples are planned to be tested by dissolving a drop of dyes or inks of an amorphous carbon film protected by a 400 mesh copper grid and by evaporating solvent at room air temperature. The average diameter of the current dyes or inks was estimated from the average diameter of 100 nanoparticles in the microphotographs in many randomly chosen regions [35-37].

The Ultrasonic Processor used in this work is (SONICS\&MATERIALS, INC), Model: VCX750, Volts: 230VAC 50/60 HZNOM, U.S.A), (The Probe is turning to resonate at a specific frequency, $20 \mathrm{KHz} \pm 100 \mathrm{HZ}$ ).

For the estimation of the element percent, the samples were investigated using AXIOS advanced, Sequential WD-XRF Spectrometer, Panalytical, 2005. The Axios is a linear instrument with a measurement channel centered on a single goniometer, spanning the whole measurement spectrum. The instrument is managed from an external computer by a microprocessor, running an analytical software program.

The color strength and whiteness degrees of the printed samples were evaluated by Hunter Lab Ultra Scan PRO, USA [38-42]. 
<smiles>[R]N=Nc1nc(N)sc1[R4]</smiles>

a<smiles>[R]c1ccc2nc(N)sc2c1</smiles><smiles>[R4]C</smiles>

b<smiles>[R]#Cc1ccc2sc(N)nc2c1</smiles>

c<smiles>[R]=Cc1cnc(N)s1</smiles>

d<smiles>[R]c1cnc(N)s1</smiles>

e

R:<smiles>Nc1ncc(-c2ccccc2)s1</smiles><smiles>[Z12]C</smiles>

f

R:<smiles>C/C=C/C</smiles><smiles>[R1]C</smiles>

R':<smiles>c1ccccc1</smiles>

Scheme 1. Suggested mechanism for azo dyes synthesis.

The colorfastness to washing was determined according to the AATCC Test method 61- 2013 using Launder-Ometer [43]. The specimens $(5 \times 10 \mathrm{~cm})$ were sewed between two similar bleached cotton fabric and wool fabric pieces. The composite specimen was immersed into an aqueous solution containing $5 \mathrm{~g} / 1$ soap and $2 \mathrm{~g} / \mathrm{l}$ sodium carbonate using a material to liquor ratio of 1:50. The bath was thermostatically adjusted to $95^{\circ} \mathrm{C}$. The test was run for 45 min at $42 \mathrm{rpm}$. The samples were then removed, rinsed twice in $100 \mathrm{ml}$ bath of water at $40^{\circ} \mathrm{C}$ for one minute with occasional stirring or hand squeezing, souring in $100 \mathrm{ml}$ of $0.014 \%$ solution 
of acetic acid for one minute at $27^{\circ} \mathrm{C}$, rinsing again for one minute in $100 \mathrm{ml}$ water at $27^{\circ} \mathrm{C}$ followed by drying $[44,45]$. Evaluation of the wash fastness was established using the Gray Scale reference for color change.

The colorfastness to crocking was determined according to the AATCC test method 8 - 2016 [46]. This test is designated for determining the degree of color, which may be transferred from the surface of the colored fabric to another surface by rubbing. A colored test specimen fastened to the base of a Crock Meter was rubbed with a white crock test cloth under controlled conditions.

Dry Rubbing Test: The test specimen was placed flat on the base of the Crock Meter. A white testing cloth was mounted on the finger of the crock meter. The covered finger was lowered onto the test specimen and caused to slide back and forth 20 times by making ten complete turns at a rate of one turn/second. The evaluation was done using the Gray Scale for staining.

Wet Rubbing test: The white test sample was thoroughly wetted out in distilled water to a $65 \%$ wet pick up. The procedure was run as before. The white test samples were then airdried before evaluation.

The colorfastness to perspiration was determined according to the AATCC test method 15 - 2013 [47]. Two artificial perspiration solutions were prepared as follows: Acidic solution: L. Histidine mono-hydrochloride monohydrate $0.5 \mathrm{~g}$, sodium chloride $5.0 \mathrm{~g}$, sodium dihydrogen orthophosphate $2.2 \mathrm{~g}$, were dissolved in $1 \mathrm{~L}$ distilled water. Finally, the $\mathrm{pH}$ was adjusted to $\mathrm{pH} 5.5$ by $\mathrm{NaOH}$ solution $0.1 \mathrm{~N}$. Alkaline solution: L. Histidine monohydrochloride monohydrate $0.5 \mathrm{~g}$, sodium chloride $5.0 \mathrm{~g}$ di-sodium hydrogen orthophosphate $2.5 \mathrm{~g}$, was dissolved in $1 \mathrm{~L}$ distilled water. Finally, the $\mathrm{pH}$ was adjusted to $\mathrm{pH} 8$ by $\mathrm{NaOH}$ solution $0.1 \mathrm{~N}$.

The colorfastness to light was determined according to the AATCC test method 16.1 2014 [48].

\section{Results and Discussion}

\subsection{Synthesis of azo dyes.}

The diazotization process typically happens below $0^{\circ} \mathrm{C}$, and when this process occurs at $0-10^{\circ} \mathrm{C}$, diazonium salts are formed with reduced thermal stability. In this study, the produced heteroaryl diazonium salts using nano $\mathrm{BF}_{3} . \mathrm{SiO}_{2}$. It was observed to be stable enough to be kept at a normal temperature in the dry grinding method. Amine (benzo[d]thiazole-2amine, 5-methyl thiazole-2-amine, and 5-phenylthiazole-2-amine,), were rapidly reacted with heterocyclic couplers to produce the azo dyes in the existence of $\mathrm{NaNO}_{2}$ and $\mathrm{BF}_{3} \cdot \mathrm{SiO}_{2}(\mathrm{Scheme}$ 1 and Table 1).

Table 1. Average molecular size of origin synthesized dyes and nano - inks.

\begin{tabular}{l|c|c} 
Ink no. & $\begin{array}{c}\text { The average molecular size of origin } \\
\text { synthesized dyes (nanoscale) }\end{array}$ & $\begin{array}{c}\text { The average molecular size of } \\
\text { microencapsulated inks (nanoscale) }\end{array}$ \\
\hline $\mathrm{a}$ & 305.87 & 18.33 \\
\hline $\mathrm{b}$ & 205.79 & 20.35 \\
\hline $\mathrm{c}$ & 218.01 & 14.55 \\
\hline $\mathrm{d}$ & 102.61 & 46.12 \\
\hline $\mathrm{e}$ & 355 & 60.75 \\
\hline $\mathrm{f}$ & 500 & 45.66
\end{tabular}

Figure 1 and Figure 2 show Transmission electron microscopy (TEM) images of synthesized dyes and nano-inks morphology. It's clear from images that the synthesized dyes' 
average particle diameter is greater than $100 \mathrm{~nm}$. But nano ink average particle diameter ranging from 14 to $60 \mathrm{~nm}$.

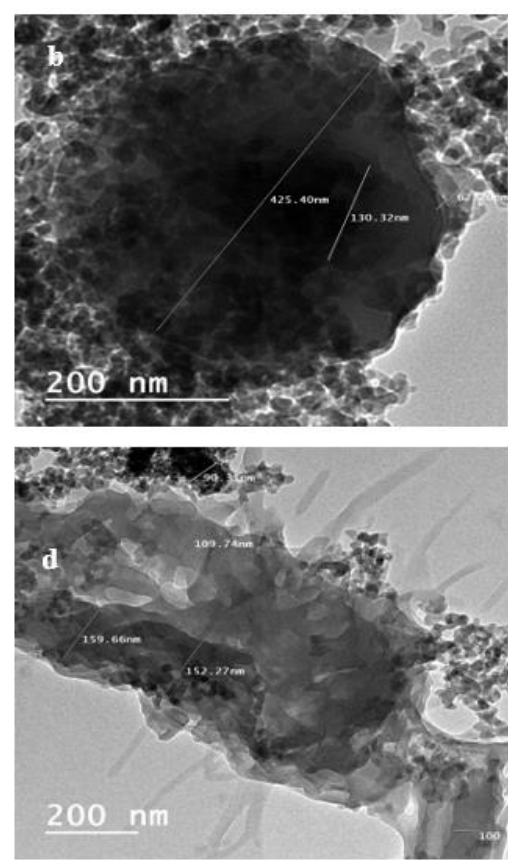

Figure 1. TEM image of synthesized dyes (a-d) respectively.
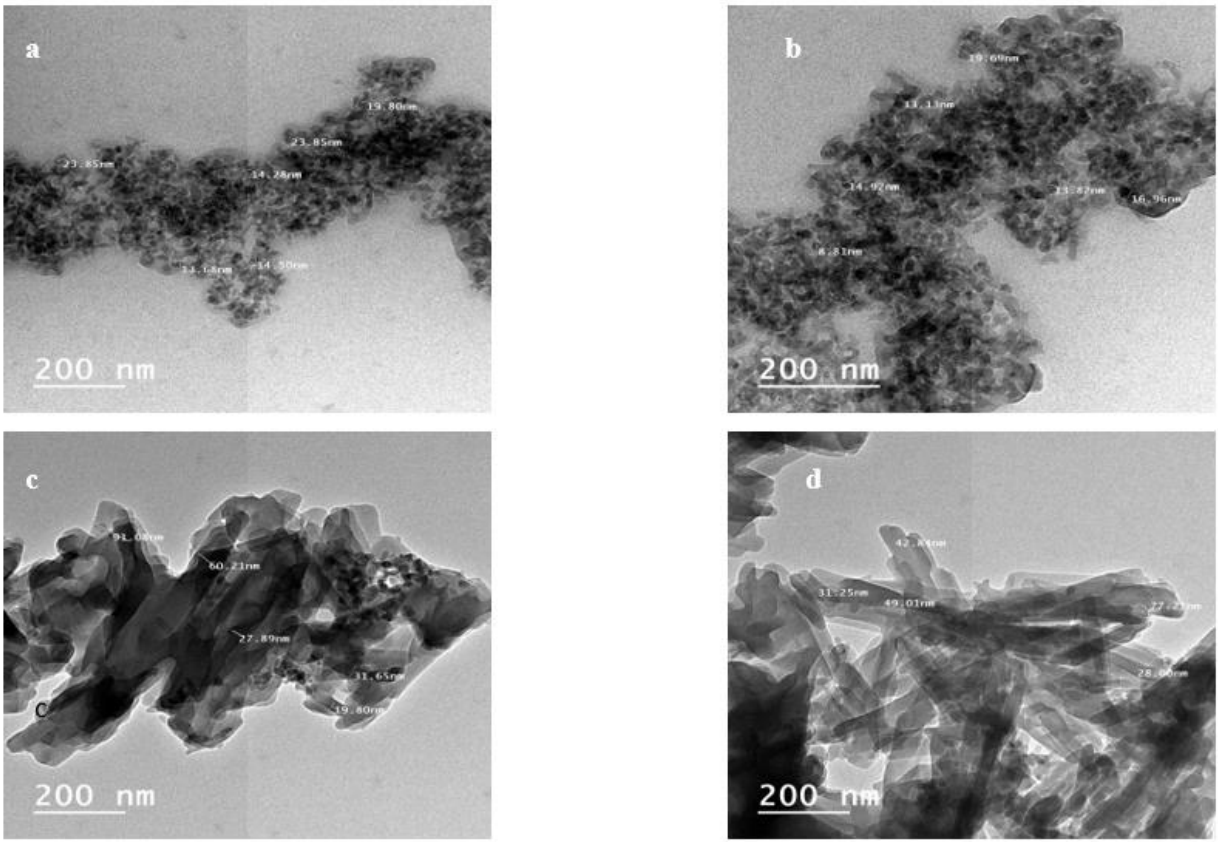

Figure 2. TEM images of microencapsulation inks (a-d), respectively.

Table 2. Colour assessment for inkjet-printed samples.

\begin{tabular}{l|c|c|c|c|c|c} 
Ink No. & $\begin{array}{c}\lambda_{\max } \\
(\mathbf{n m})\end{array}$ & $\mathbf{K} / \mathbf{S}$ (cotton) & $\begin{array}{c}\mathbf{K} / \mathbf{S} \\
\text { (polyamide) }\end{array}$ & $\mathbf{L}^{*}$ & $\mathbf{a}^{*}$ & $\mathbf{b}^{*}$ \\
\hline $\mathrm{a}$ & 445 & 19.2 & 19.2 & 77.23 & 5.82 & 32.34 \\
\hline $\mathrm{b}$ & 477 & 18.34 & 20.24 & 78.2 & 6.77 & 43.21 \\
\hline $\mathrm{c}$ & 483 & 16.1 & 18.1 & 67.72 & 6.42 & 42.51 \\
\hline $\mathrm{d}$ & 512 & 25.2 & 27.2 & 81.23 & 6.56 & 32.78 \\
\hline $\mathrm{e}$ & 495 & 24.2 & 26.2 & 79.3 & 4.21 & 45.23 \\
\hline $\mathrm{f}$ & 475 & 23.4 & 24.2 & 69.45 & 5.13 & 39.21
\end{tabular}

Table 2 represents the color assessments of prepared inks that showed positive values for a* "red-green axis" on cotton and polyamide fabrics that is pointed to the reddish direction https://biointerfaceresearch.com/ 
and positive values for $\mathrm{b}^{*}$ "yellow-blue axis" on cotton and polyamide fabrics that is pointed to the yellow direction.

It can also be seen that the inks no. ( $\mathrm{d}$ and e possess) the highest values of color strength are the molecular structure of the two inks containing phenyl groups (electron-donating) bound to the first thiazole ring and the methyl group (electron-withdrawing) on the other thiazole ring, which result in the bathochromic shift.

Table 3 and Table 4 represent the fastness properties of inkjet-printed samples using the newly synthesized inks. The data show that excellent fastness due to the smaller particle size of inks. Figure 3 shows digital photographs for digital and brush printed cotton and polyamide fabrics using nano inks.
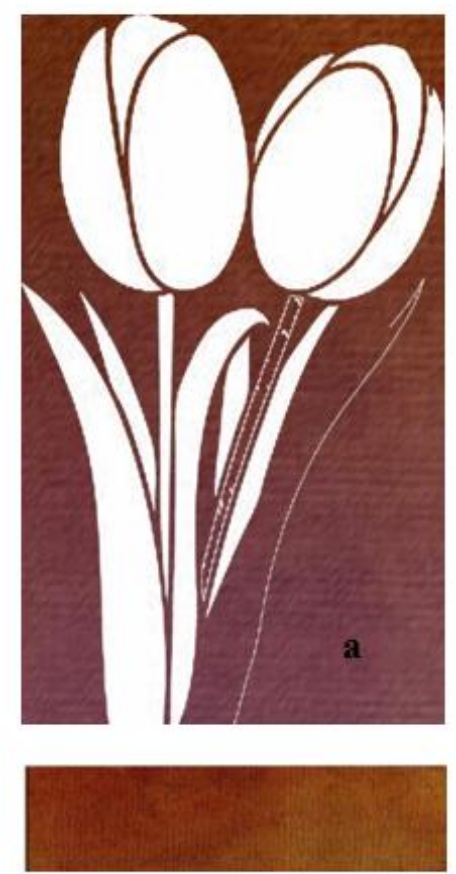

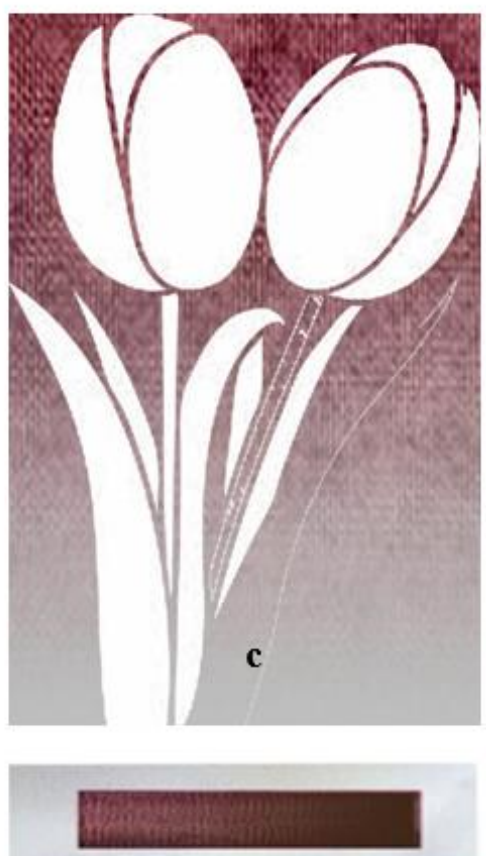

Figure 3. Digital photographs for digital and brush printed cotton fabrics using nano inks.

Table 3. Fastness Properties of Inkjet Printing cotton Fabric Using the Newly Synthesized inks (a - f).

\begin{tabular}{|c|c|c|c|c|c|c|c|c|c|}
\hline \multirow{3}{*}{$\begin{array}{l}\text { Ink } \\
\text { No. }\end{array}$} & \multicolumn{2}{|c|}{ Rubbing } & \multicolumn{2}{|c|}{ Washing } & \multicolumn{4}{|c|}{ Perspiration } & \multirow{3}{*}{$\begin{array}{l}\text { Light- } \\
\text { fastness }\end{array}$} \\
\hline & \multirow{2}{*}{ Dry } & \multirow{2}{*}{ Wet } & \multirow{2}{*}{ Alt. } & \multirow{2}{*}{ St. } & \multicolumn{2}{|c|}{ Alkali } & \multicolumn{2}{|c|}{ Acid } & \\
\hline & & & & & Alt & St. & Alt. & St. & \\
\hline $\mathrm{a}$ & $4-5$ & 4 & $4-5$ & 4 & $4-5$ & 4 & 4 & 4 & 5 \\
\hline $\mathrm{b}$ & 5 & $4-5$ & 5 & 5 & 5 & 5 & 5 & 5 & 5 \\
\hline c & $4-5$ & $4-5$ & 5 & 5 & 5 & 5 & 5 & 5 & $5-6$ \\
\hline $\mathrm{d}$ & $4-5$ & 4 & 5 & 5 & 5 & 5 & 5 & 5 & $5-6$ \\
\hline $\mathrm{e}$ & $4-5$ & 4 & 5 & 5 & 5 & 5 & 5 & 5 & $5-6$ \\
\hline$f$ & $4-5$ & $4-5$ & 5 & 5 & 5 & 5 & 5 & 5 & $5-6$ \\
\hline
\end{tabular}

Table 4. Fastness properties of inkjet printing polyamide fabric using the newly synthesized inks (a - f).

\begin{tabular}{|c|c|c|c|c|c|c|c|c|c|}
\hline \multirow{3}{*}{$\begin{array}{l}\text { Ink } \\
\text { No. }\end{array}$} & \multicolumn{2}{|c|}{ Rubbing } & \multicolumn{2}{|c|}{ Washing } & \multicolumn{4}{|c|}{ Perspiration } & \multirow{3}{*}{$\begin{array}{l}\text { Light- } \\
\text { fastness }\end{array}$} \\
\hline & \multirow{2}{*}{ Dry } & \multirow{2}{*}{ Wet } & \multirow{2}{*}{ Alt. } & \multirow{2}{*}{ St. } & \multicolumn{2}{|c|}{ Alkali } & \multicolumn{2}{|c|}{ Acid } & \\
\hline & & & & & Alt & St. & Alt. & St. & \\
\hline $\mathrm{a}$ & $4-5$ & 4 & $4-5$ & 4 & 5 & 5 & 5 & 5 & 5 \\
\hline $\mathrm{b}$ & $4-5$ & $4-5$ & 5 & $4-5$ & 5 & 5 & 5 & 5 & $5-6$ \\
\hline c & 5 & $4-5$ & 5 & 5 & 5 & 5 & 5 & 5 & $5-6$ \\
\hline $\mathrm{d}$ & 5 & $4-5$ & 5 & 5 & 5 & 5 & 5 & 5 & $5-6$ \\
\hline $\mathrm{e}$ & 5 & $4-5$ & $4-5$ & $4-5$ & 5 & 5 & 5 & 5 & $5-6$ \\
\hline$f$ & 5 & $4-5$ & 5 & 5 & 5 & 5 & 5 & 5 & 5 \\
\hline
\end{tabular}


Figure 4 and Figure 5 show the effect of fixation time $(1-5 \mathrm{~min})$ at $150^{\circ} \mathrm{C}$ on the brush printed cotton and polyamide using the synthesized inks. The highest values of color strength are acquired at a fixation time of $5 \mathrm{~min}$.

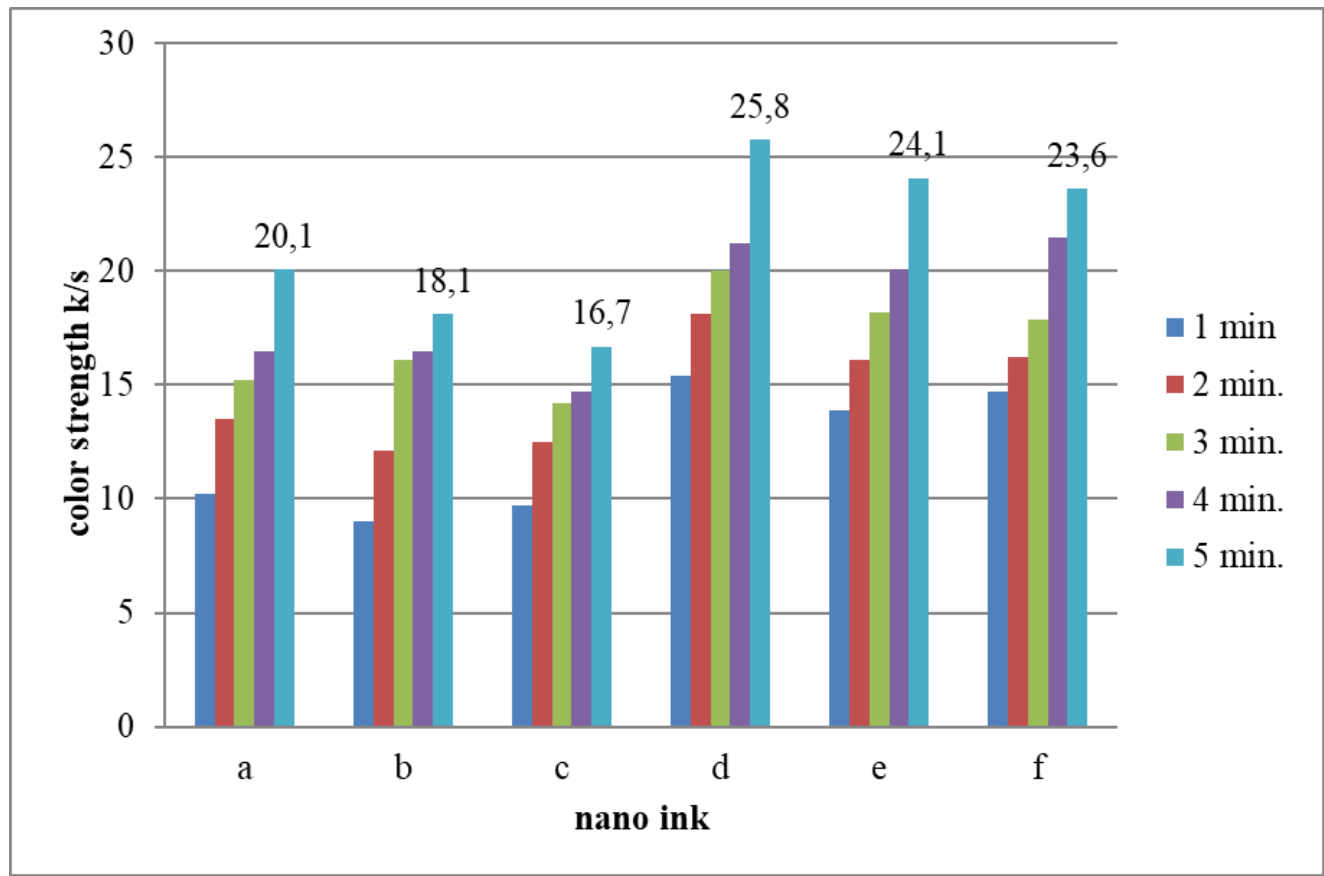

Figure 4. Fixation time effect on the K/S of digitally printed cotton.

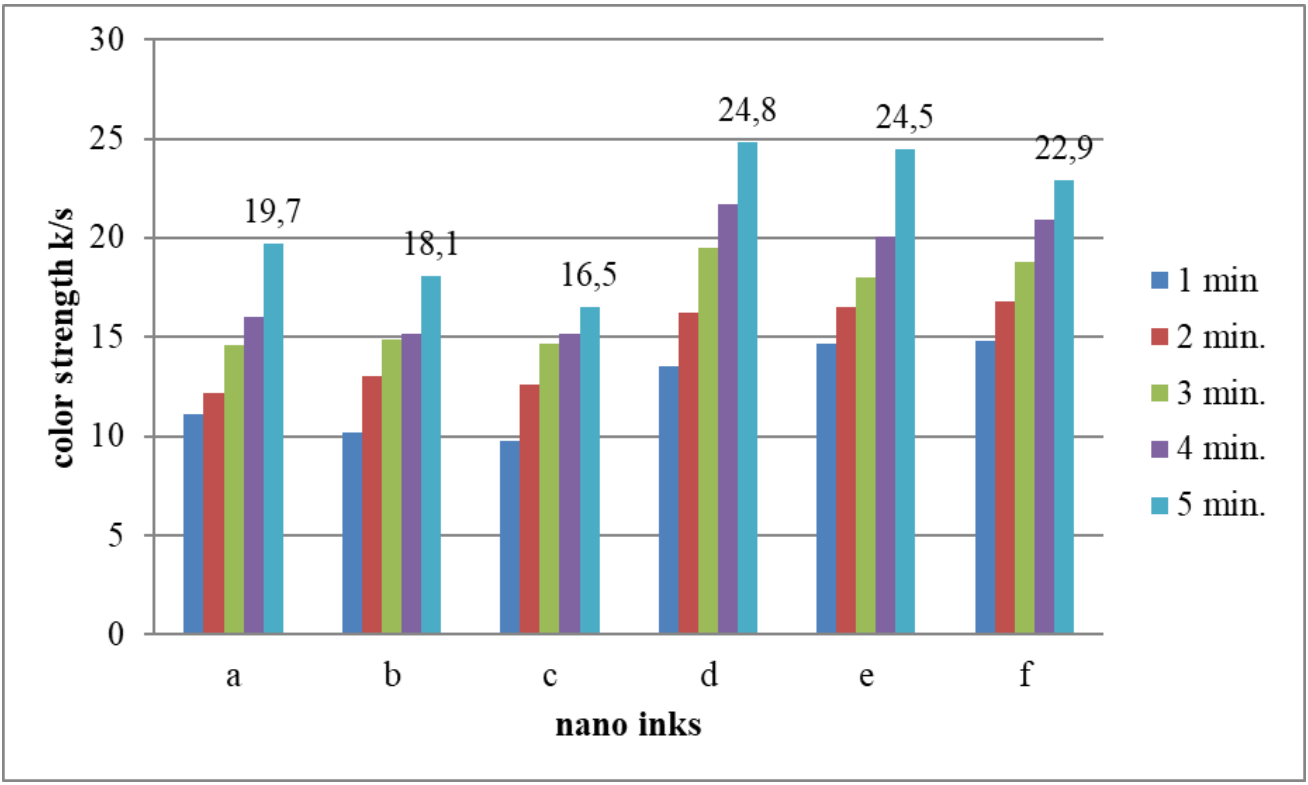

Figure 5. Fixation time effect on the K/S of digitally printed polyamide.

\section{Conclusions}

$\mathrm{BF}_{3} . \mathrm{SiO}_{2}$ is used as an acid catalyst, which promotes the diazotization and coupling of heterocyclic compounds at room temperature. This process saves time, energy and reduces the operation cost because the reaction takes place at room temperature without the addition of solvents. The produced compounds are used as inks in printing cotton and polyamide fabrics; the prints have very good fastness properties. 


\section{Funding}

This research received no external funding.

\section{Acknowledgments}

We are gratefully thankful to National Research Centre, Egypt, for provided facilities.

\section{Conflicts of Interest}

The authors declare no conflict of interest.

\section{References}

1. Benkhaya, S.; M'Rabet, S.; El Harfi, A. Classifications, properties, recent synthesis and applications of azo dyes. Heliyon 2020, 6, e03271-e03271, https://doi.org/10.1016/j.heliyon.2020.e03271.

2. Carmen, Z.; Daniel, S. Textile organic dyes - characteristics, polluting effects and separation/elimination procedures from industrial effluents - a critical overview. In: Organic pollutants ten years after the stockholm convention - environmental and analytical update. Puzyn, T. Ed. InTech: 2012.

3. Benkhaya, S.; M' rabet, S.; El Harfi, A. A review on classifications, recent synthesis and applications of textile dyes. Inorg. Chem. Commun. 2020, 115, https://doi.org/10.1016/j.inoche.2020.107891.

4. Aboelnaga, A.; Shaarawy, S.; Hassabo, A.G. Polyaconitic acid/functional amine/azo dye composite as a novel hyper-branched polymer for cotton fabric functionalization. Colloids Surf. B: Biointer. 2018, 172, 545554, https://doi.org/10.1016/j.colsurfb.2018.09.012.

5. Ghasemi, Z.; Azizi, S.; Salehi, R.; Kafil, H.S. Synthesis of azo dyes possessing n-heterocycles and evaluation of their anticancer and antibacterial properties. Monatshefte für Chemie - Chemical Monthly 2018, 149, 149157, https://doi.org/10.1007/s00706-017-2073-y.

6. Kosolia, C.T.; Tsatsaroni, E.G. Synthesis and characterization of hetarylazo disperse colorants: Preparation and properties of conventional and microemulsified inks for polyester inkjet printing. J. Appl. Polym. Sci. 2010, 116, 1422-1427, https://doi.org/10.1002/app.30879.

7. Gao, C.; Xing, T.; Hou, X.; Chen, G. Preparation of disperse inks for direct inkjet printing of non-pretreated polyester fabrics. RSC Adv. 2019, 9, 19791-19799, https://doi.org/10.1039/c9ra01999e.

8. El-Kashouti, M.; Elhadad, S.; Abdel-Zaher, K. Printing technology on textile fibers: Review. Journal of $\begin{array}{llllll}\text { Textiles, } \quad \text { Coloration and Polymer } & \text { Science }\end{array}$ https://doi.org/10.21608/jtcps.2019.15989.1027.

9. Rufchahi, E.O.M.; Gilani, A.G.; Taghvaei, V.; Karimi, R.; Ramezanzade, N. Synthesis, structural elucidation, solvatochromism and spectroscopic properties of some azo dyes derived from 6-chloro-4hydroxyquinoline-2(1h)-one. Journal of Molecular Structure 2016, 1108, 623-630, https://doi.org/10.1016/j.molstruc.2015.12.001.

10. Moradi Rufchahi, E.O.; Ghanadzadeh Gilani, A. Aryl and heteroaryl azo dyes derived from 6, 8-dichloro-4hydroxyquinolin-2 (1 h )-one: Synthesis, characterisation, solvatochromism and spectroscopic properties. Color. Technol. 2019, 135, 391-406, https://doi.org/10.1111/cote.12426.

11. Abu-Melha, S. Synthesis of novel biologically active thiazole dyes and their applications. Pigm. Resin Technol. 2019, 48, 375-382, https://doi.org/10.1108/prt-09-2018-0102.

12. Valizadeh, H.; Shomali, A.; Nourshargh, S.; Mohammad-Rezaei, R. Carboxyl and nitrite functionalized graphene quantum dots as a highly active reagent and catalyst for rapid diazotization reaction and synthesis of azo-dyes under solvent-free conditions. Dyes Pigments 2015, 113, 522-528, https://doi.org/10.1016/j.dyepig.2014.09.023.

13. Khattab, T.; Rehan, M. A review on synthesis of nitrogen-containing heterocyclic dyes for textile fibers part 1: Five and six-membered heterocycles. Egy. J. Chem. 2018, 61, 897-937, https://doi.org/10.21608/ejchem.2018.4130.1362.

14. Patil, C.J.; Rajput, S.V. Coupling reactions involving aryldiazonium salt: Part-ix. Review on synthesis of azo-phenolic derivatives, their applications and biological activities. International Journal of Recent Scientific Research 2019, 10, 32144-32156.

15. Singh, P.K.; Singh, R.L. Bio-removal of azo dyes: A review. International Journal of Applied Sciences and Biotechnology 2017, 5, https://doi.org/10.3126/ijasbt.v5i2.16881.

16. Bamoniri, A.; Mirjalili, B.B.F.; Moshtael-Arani, N. Environmentally green approach to synthesize azo dyes based on 1-naphthol using nano bf3.sio2under solvent-free conditions. Green Chemistry Letters and Reviews 2014, 7, 393-403, https://doi.org/10.1080/17518253.2014.969786.

17. Filimonov, V.D.; Krasnokutskaya, E.A.; Kassanova, A.Z.; Fedorova, V.A.; Stankevich, K.S.; Naumov, N.G.; Bondarev, A.A.; Kataeva, V.A. Synthesis, structure, and synthetic potential of arenediazonium 
trifluoromethanesulfonates as stable and safe diazonium salts. Eur. J. Org. Chem. 2019, 2019, 665-674, https://doi.org/10.1002/ejoc.201800887.

18. Khattab, T.A.; Mohamed, A.L.; Hassabo, A.G. Development of durable superhydrophobic cotton fabrics coated with silicone/stearic acid using different cross-linkers. Materials Chemistry and Physics 2020, 249, https://doi.org/10.1016/j.matchemphys.2020.122981.

19. Mohamed, A.L.; Hassabo, A.G. Review of silicon-based materials for cellulosic fabrics with functional applications. Journal of Textiles, Coloration and Polymer Science 2019, 16, 139-157, https://doi.org/10.21608/JTCPS.2019.18580.1030.

20. Hassabo, A.G.; Mohamed, A.L.; Shaarawy, S.; Hebeish, A. Novel micro-composites based on phosphorylated biopolymer/polyethyleneimine/clay mixture for cotton multi-functionalities performance. Biosci. Res. 2018, 15, 2568-2582.

21. Mohamed, A.L.; Hassabo, A.G. Composite material based on pullulan/silane/zno-nps as ph, thermosensitive and antibacterial agent for cellulosic fabrics. Advances in Natural Science: Nanoscience and Nanotechnolgy 2018, 9, 045001-045009, https://doi.org/10.1088/2043-6254/aaeee0.

22. Mohamed, A.L.; El-Naggar, M.E.; Shaheen, T.I.; Hassabo, A.G. Laminating of chemically modified silan based nanosols for advanced functionalization of cotton textiles. Int. J. Biol. Macromol. 2017, 95, 429-437, https://doi.org/10.1016/j.ijbiomac.2016.10.082.

23. Luo, Y.; Pei, L.; Zhang, H.; Zhong, Q.; Wang, J. Improvement of the rubbing fastness of cotton fiber in indigo/silicon non-aqueous dyeing systems. Polymers (Basel) 2019, 11, https://doi.org/10.3390/polym11111854.

24. Shahidi, S.; Wiener, J.; Ghoranneviss, M. Surface modification methods for improving the dyeability of textile fabrics. InTech: 2013; https://doi.org/10.5772/53911.

25. Pargai, D.; Jahan, S.; Gahlot, M. Functional properties of natural dyed textiles. IntechOpen: 2020; https://doi.org/10.5772/intechopen.88933.

26. Kumar Gupta, V. Fundamentals of natural dyes and its application on textile substrates. IntechOpen: 2020.

27. Sadeghi, B.; Mirjalili, B.B.F.; Hashemi, M.M. Bf3.sio2: An efficient reagent system for the one-pot synthesis of 1,2,4,5-tetrasubstituted imidazoles. Tetrahedron Lett 2008, 49, 2575-2577.

28. Mirjalili, B.F.; Bamoniri, A.; Akbari, A. One-pot synthesis of 3,4-dihydropyrimidin-2(1h)-ones (thiones) promoted by nano-bf3.Sio2. Journal of the Iranian Chemical Society Reviews 2011, 8, S135-S140, https://doi.org/10.1007/bf03254290.

29. Mirjalili, B.F.; Bamoniri, A.; Rahmati, L. One-pot synthesis of 1-amidoalkyl-2-naphthols catalyzed by nanobf3·sio2. Arabian Journal of Chemistry 2019, 12, 2216-2223, https://doi.org/10.1016/j.arabjc.2014.12.026.

30. Gorlushko, D.A.; Filimonov, V.D.; Semenishcheva, N.I.; Krasnokutskaya, E.A.; Tret'Yakov, A.N.; Go, B.S.; Hwang, H.Y.; Cha, E.H.; Chi, K.-W. A simple and efficient procedure for diazotization-iodination of aromatic amines in aqueous pastes by the action of sodium nitrite and sodium hydrogen sulfate. Russian Journal of Organic Chemistry 2008, 44, 1243-1244, https://doi.org/10.1134/s1070428008080253.

31. Leelajariyakul, S.; Noguchi, H.; Kiatkamjornwong, S. Surface-modified and micro-encapsulated pigmented inks for ink jet printing on textile fabrics. Prog. Org. Coat. 2008, 62, 145-161, https://doi.org/10.1016/j.porgcoat.2007.10.005.

32. Hakeim, O.; Diab, H.A.; Adams, J. Preparation and characterization of uv curable-encapsulated phthalocyanine blue pigment. Prog. Org. Coat. 2015, 84, https://doi.org/10.1016/j.porgcoat.2015.02.007.

33. Hassabo, A.G.; Salama, M.; Popescu, C. Characterizations of PVA composites based on recycled ultrafine cotton and wool powders. Res. Rev. BioSci. 2015, 10, 147-158.

34. Elshemy, N.S.; Nassar, S.H.; El-Taieb, N.M.; Shakour, A.A.A.; Elmekawy, A.M.; Hassabo, A.G. Effect of different fabrics types on the adsorption of air pollution in residential and industrial atmosphere in cairoegypt. Letters in Applied NanoBioScience 2019, 9, 682 - 691, https://doi.org/10.33263/LIANBS84.682691.

35. Hassabo, A.G. Preparation, characterisation and utilization of some textile auxiliaries. Textile Chemistry, El-Azhar University, Cairo, Egypt, 2005.

36. Hassabo, A.G.; Mendrek, A.; Popescu, C.; Keul, H.; Möller, M. Deposition of functionalized polyethylenimine-dye onto cotton and wool fibres. RJTA 2014, 18, 36-49, https://doi.org/10.1108/RJTA-1801-2014-B006.

37. Hassabo, A.G.; Erberich, M.; Popescu, C.; Keul, H. Functional polyethers for fixing pigments on cotton and wool fibres. Res. Rev. Polym. 2015, 6, 118-131.

38. Kubelka, P.; Munk, F. Ein beitrag zur optik der farbanstriche. Z. Tech. Phys. 1931, 12, https://doi.org/10.1007/978-3-642-27851-8_300-1.

39. Mehta, K.T.; Bhavsar, M.C.; Vora, P.M.; Shah, H.S. Estimation of the kubelka--munk scattering coefficient from single particle scattering parameters. Dyes Pigments 1984, 5, 329-340, https://doi.org/10.1016/01437208(84)80027-3.

40. Waly, A.; Marie, M.M.; Abou-Zeid, N.Y.; El-Sheikh, M.A.; Mohamed, A.L. In: Process of single - bath dyeing, finishing and flam - retarding of cellulosic textiles in presence of reactive tertiary amines. $3^{\text {rd }}$ International Conference of Textile Research Division, NRC; Textile Processing: State of the Art \& Future Developments, Cairo, Egypt, 2 - 4 April, Cairo, Egypt, 2006; pp 529-543. 
41. Abo-Shosha, M.H.; Nassar, F.A.; Haggag, K.; El-Sayed, Z.; Hassabo, A.G. Utilization of some fatty acid/peg condensates as emulsifiers in kerosene paste pigment printing. RJTA 2009, 13, 65-77.

42. Hassabo, A.G. Synthesis and deposition of functional nano-materials on natural fibres. Polymer Chemistry, RWTH Aachen University, Germany, 2011.

43. AATCC Test Method (61-2013). Color fastness to laundering: Accelerated. In: Technical Manual Method. American Association of Textile Chemists and Colorists: 2017; pp. 108.

44. Waly, A.; Marie, M.M.; Abou-Zeid, N.Y.; El-Sheikh, M.A.; Mohamed, A.L. Flame retarding, easy care finishing and dyeing of cellulosic textiles in one bath. Egypt. J. Text. Polym. Sci. Technol. 2008, 12, 101131 ,

45. Waly, A.I.; Marie, M.M.; Abou-Zeid, N.Y.; El-Sheikh, M.A.; Mohamed, A.L. Processes of dyeing, finishing and flame retardancy of cellulosic textiles in the presence of reactive tertiary amines. RJTA 2012, 16, 66-84, https://doi.org/10.1108/RJTA-16-03-2012-B007.

46. AATCC Test Method (8-2016). Colorfastness to crocking. Crockmeter method. In: Technical Manual Method. American Association of Textile Chemists and Colorists: Volume 86, 2018; pp. 17-19.

47. AATCC Test Method (15-2013). Colour fastness to perspiration. In: Technical Manual Method. American Association of Textile Chemists and Colorists: Volume 86, 2017; pp. 30-32.

48. AATCC Test Method (16.1-2014). Colour fastness to light: Outdoor. In: Technical Manual Method. American Association of Textile Chemists and Colorists: Volume 16.1, 2015; pp. 33-48. 